\title{
Analisis Sistem Pengendalian Internal Pada Lembaga Amil Zakat Al Azhar
}

\author{
Andrean Muhammad Anwar ${ }^{1}$, Krisno Septyan $^{2}$ \\ ${ }^{1,2}$ Fakultas Ekonomi dan Bisnis Universitas Pembangunan Nasional Veteran Jakarta, Jakarta \\ 1 andre.muhan53@gmail.com
}

\begin{abstract}
This study aims to analyze the implementation of the internal control system in the collection process until the distribution of zakat funds in this study was conducted at the Al Azhar Amil Zakat Institution, this research is a qualitative research using a phenomenological approach. Based on the results of this study revealed that the Amil Al Azhar Institution in 1) The control environment in the aspect of integrity and ethical values always emphasizes the standards determined by the center. 2) Risk withdrawal is carried out with each transaction known to the Branch Leader and inputted using the system then for internal changes such as the presence of new employees and the risk assessment. 3) Control activities are carried out by ensuring that the quality of transaction authorization is guaranteed by donors coming to the office for transactions to always fill in the proof of deposit. Good safeguards for assets and independent checks are carried out every few months. 4) Information and communication is carried out by always using the custumer service and internal information systems. There is good communication between divisions. 5) Monitoring mechanism is carried out by monitoring internal and external parties

Keywords: Internal Control_1, Zakat Collection_2, Zakat Distribution_3
\end{abstract}

\section{PENDAHULUAN}

Entitas dibagi menjadi 2 golongan yaitu entitas yang profit oriented dan entitas nirlaba. Entitas profit oriented memperoleh sumber daya dari para stakeholder yang mengharapkan imbal hasil atas sumber daya yang telah diberikan tersebut, sedangkan entitas nirlaba adalah entitas yang memperoleh sumber daya untuk menjalankan operasinya dari sumbangan yang diberikan oleh anggota maupun penyumbang dari bukan anggota yang tidak mengharapkan imbal hasil.

Organisasi Pengelola Zakat (OPZ) merupakan entitas nirlaba yang yang kegiatannya melakukan perencanaan, pelaksanaan, dan pengoordinasian dalam penghimpunan dana zakat, infaq dan shadaqah (ZIS), pengelola dana sebagai amil harus menentukan proporsi pembagian dana maupun siapa yang berhak menerima dana tersebut.

Data potensi dana zakat yang dikeluarkan oleh berbagai lembaga memang sangat tinggi dan direktur operasional ziswaf di Lembaga Amil Zakat Al Azhar bapak Ahidin (2018) menjelaskan bahwa benar memang potensi zakat di Indonesia sangatlah besar. "iya memang benar potensi zakat di Indonesia memang sangat besar bukan hoax itu, coba mas bayangkan saja berapa uang yang diambi dari bank di seluruh Indonesia ketika lebaran, banyak kan? Oleh sebab itu terjadi pemerataan ketika lebaran"

Tabel 1. Potensi dan Realisasi Dana Zakat

\begin{tabular}{llll}
\multicolumn{4}{c}{ di Indonesia } \\
\hline Tahun & Lembaga & Potensi & Realisasi \\
\hline $\mathbf{2 0 0 9}$ & $\begin{array}{l}\text { Indonesia } \\
\text { Economic } \\
\text { outlook }\end{array}$ & Rp. 12,7 triliun & Rp. 1,2 triliun \\
\hline $\mathbf{2 0 1 1}$ & $\begin{array}{l}\text { FEM IPB } \\
\text { dan } \\
\text { BAZNAS }\end{array}$ & Rp. 217 triliun & $\begin{array}{l}\text { Rp. } 1,729 \\
\text { triliun }\end{array}$ \\
\hline $\mathbf{2 0 1 5}$ & BAZNAS & Rp. 286 triliun & $\begin{array}{l}\text { Rp. 3,653 } \\
\text { triliun }\end{array}$ \\
\hline
\end{tabular}

Sumber: outlook zakat 2018

Potensi Zakat di Indonesia yang sangat besar ternyata berbanding terbalik dengan realisasi yang terjadi secara aktual dapat dilihat dari tabel 1 menyatakan bahwa dalam perkembangannya dari tahun 2009 sampai 2015 realisasi penghimpunan dana zakat belum mencapai potensinya bahkan jauh dari potensi dana zakat tersebut. Ahidin (2018) menjelaskan ada 3 faktor yang membuat potensi zakat tersebut belum terealisasi.

\footnotetext{
"pertama budaya masyarakat kita yang lebih suka memberi angpao secara langsung orang diundang kerumahnya untuk berbagi sedekah. Lalu yang kedua
} 
regulasi yang kurang tegas. Dan yang ketiga adalah kepercayaan masyarakat kepada LAZ itu kurang karena mungkin ya dia membayar zakat di LAZ yang tidak terdaftar di Kementrian agama dan dana zakat tersebut tidak diketahui disalurkan kemana"

Penyebab tidak tercapainya potensi zakat menurut informan ada tiga yang telah di sebutkan diatas, ketidakpercayaan masyarakat merupakan salah satu faktor yang membuat realisasi dana zakat tidak tercapai dari potensinya. Salah satu Organisasi Pengelolaan Zakat di Indonesia adalah Lembaga Amil Zakat (LAZ) Al Azhar yang memiliki motif untuk tidak mengambil keuntungan dalam kegiatan operasinya. Namun jika pengelolaan tidak dilakukan dengan professional maka kepercayaan publik terhadap LAZ Al Azhar akan hancur dan masyarakat tidak akan memilih LAZ lagi untuk opsi dalam pembayaran zakat. Oleh sebab itu LAZ menggunakan prinsip seperti entitas bisnis untuk akuntabilitas dan professional dalam bekerja agar lebih transparan dan dipercaya oleh stakeholders.

Tujuan sistem pengendalian internal adalah memberikan tingkat keyakinan yang wajar pada efektifitas dan efisiensi aktivitas, Pelaporan keuangan di sajikan secara wajar, ketaatan terhadap peraturan perundangundangan yang berlaku, dan mengamankan asset terhadap pencatatan, penggunaan, atau penghentian pengakuan yang tidak diotorisasi. Oleh sebab itu LAZ Al Azhar menggunakan 5 komponen dari COSO (Commitee of Sponsoring Oganizations of the Treadway Commision) untuk dapat mencapai tujuan tersebut. LAZ Al Azhar juga memiliki struktur organisasi, metode dan ukuranukuran untuk menjaga serta mengarahkan perusahaan agar bergerak sesuai dengan tujuan perusahaan dan mendorong efisiensi serta dipatuhinya kebijakan manajemen. Walaupun Lembaga Amil Zakat Al Azhar telah menerapkan sistem pengendalian internal namun kenyataannya tidak sepenuhnya berjalan dengan lancar pak Farid selaku kepala divisi keuangan menjelaskan
Kepala Administrasi harusnya tidak melakukan itu. suatu kejadian yang akhirnya saya merekomendasikan Divisi Kepegawaian untuk ngasih surat peringatan.

Kegiatan operasional dari LAZ Al Azhar memang tidak pernah terjadi penyimpangan dalam bentuk pencurian uang. jika kepala administrasi melakukan hal yang tidak seharusnya dia lakukan maka dapat saja pencurian uang dapat terjadi. Oleh sebab itu sistem pengendalian internal diperlukan untuk mengamankan asset dan tujuan lainnya. Pengendalian internal juga mengarahkan karyawan untuk berbuat sesuai dengan standar operasional pekerjaannya (SOP). Jika tidak mengarahkan maka sistem pengendalian internal tersebut tidak baik karena manajemen wajib untuk menginformasikan kepada bawahannya untuk bekerja dengan integritas dan kompetensi yang baik.

Penelitian yang dilakukan oleh Nurhayati (2016) menyatakan komponen informasi dan komunikasi masih harus diperbaiki dan komponen lainnya seperti lingkungan pengendalian, penilaian resiko dan aktivitas pengendalian dianggap baik, sedangkan untuk dan pemantauan yang sudah cukup menurut peneliti. Penelitian juga dilakukan oleh Nikmatuniyah (2014) yang meninjau Lembaga Amil Zakat yang ada di kota Semarang dengan salah satu komponen pengendalian internal yaitu aktivitas pengendalian. Nikmatuniyah mengungkapkan hasil pengamatan yang menunjukkan masih terdapat kelemahan dalam kepatuhan terhadap pengendalian intern, antara lain ditunjukkan dalam hal melemahnya pemisahan tugas, pemegang otorisasi, rotasi jabatan, dokumen tidak bernomor urut tercetak, dan pengawasan internal.

\section{TELAAH LITERATUR Pengertian Zakat}

Islam memandang zakat sebagai instrumen yang penting yang bersifat mahdlah yang berarti ibadah wajib yang memiliki sistem, mekanisme, jenis dan waktu tertentu. Hafiyah berkata, penyebab zakat adalah seseorang memiliki harta 
sebesar 1 nisab yang berkembang dengan syarat genap satu tahun (haul) qamariah, dan seseorang tidak memiliki utang yang dituntut dan memiliki barang melebihi dari kebutuhan sehari-hari (Fryanti, 2017 hlm. 89) dan ghairu mahdlah adalah dimana zakat memiliki fungsi sosial berupa perlindungan bagi golongan yang membutuhkan (Kemenag, 2013 hlm.6)

Dompet Dhuafa Republika (2012) menjelaskan zakat terdiri atas 2 macam yaitu zakat nafs (jiwa) dan zakat mal (harta). Zakat mal (harta) adalah zakat yang dikeluarkan bila seseorang memiliki secara sempurna harta yang dapat dimanfaatkan secara utuh dan harta tersebut melebihi nisab atau syarat minimum harta yang dapat di kategorikan sebagai harta wajib zakat serta masa kepemilikan harta lebih dari 1 tahun (haul). Lain halnya dengan zakat mal, zakat nafs (jiwa) adalah tanda syukur umat islam setelah berlalunya ibadah puasa pada bulan ramadhan yang hukumnya wajib bagi seluruh umat islam yang merdeka maupun yang budak yang di tunaikan dengan memberikan 1 sha (di Indonesia $2,5 \mathrm{~kg}$ beras) makanan yang menjadi makanan pokok di negeri tersebut dan waktunya pun tidak boleh diluar bulan ramadhan.

Zakat yang ditunaikan oleh para muzzaki nantinya akan dikelola oleh lembaga amil yang akan menyalurkan zakatnya kepada mustahiq (orang yang berhak menerima zakat). QS. At Taubah : 60 menjelaskan bahwa terdapat 8 golongan yang termasuk mustahiq yaitu

1. Orang Fakir, yaitu orang yang sengsara dalam hidupnya, tidak mempunyai harta dan tenaga untuk memenuhi kehidupannya.

2. Orang miskin, yaitu orang yang tidak cukup untuk memenuhi kehidupannya dan dalam keadaan yang serba kekurangan.

3. Pengurus zakat ('amil), yaitu orang yang diberi wewenang untuk mengumpulkan dan membagikan dana zakat.
4. Mu'allaf, yaitu orang kafir yang ada harapan masuk islam dan orang yang baru memeluk agama islam yang imannya masih lemah.

5. Riqab, yaitu untuk memerdekakan budak, mencakup juga untuk melepaskan orang muslim yang ditawan oleh orang-orang kafir

6. Gharim, yaitu orang yang terlilit utang karena untuk kepentingan yang bukan maksiat dan tidak sanggup untuk membayarnya.

7. Sabilillah, yaitu untuk keperluan pertahanan dan kejayaan islam dan kemaslahatan kaum muslimin

8. Ibnu sabil, yaitu orang-orang yang sedang dalam perjalanan bukan maksiat yang mangamali kesengsaraan dalam perjalanannya.

\section{Sistem Pengendalian Internal}

Mulyadi (2016) menjelaskan sistem pengendalian internal meliputi struktur organisasi, metode yang dikoordinasikan untuk menjaga asset perusahaan, mengecek ketelitian dan keandalan data akuntansi, medorong efisiensi dan efektifitas serta mendorong dipatuhinya kebijakan manajemen. Definisi menekankan terhadap tujuan untuk menjaga kekayaan organisasi, mengecek ketelitian dan keandalan data akuntansi, mendorong efisiensi dan mendorong dipatuhi kebijakan manajemen dan bukan menekankan pada unsur-unsur yang membentuk pengendalian internal tersebut.

Definisi Internal Control menurut Commitee of Sponsoring Oganizations of the Treadway Commision (COSO) yang di kutip oleh Hayes (2014, hlm.260-261) adalah suatu proses yang harus dilakukan ke dalam aktivitas-aktivitas entitas yang dipengaruhi oleh dewan komisaris, manajemen, dan semua insan entitas, dirancang untuk memberikan tingkat keyakinan yang wajar untuk mencapai tujuan entitas: 
1. Aktivitas operasi berjalan dengan efektivitas dan efisiensi,

2. Pelaporan keuangan di sajikan secara wajar,

3. ketaatan terhadap peraturan perundangundangan yang berlaku, dan

4. mengamankan asset terhadap pencatatan, penggunaan, atau penghentian pengakuan yang tidak diotorisasi.

\section{Commitee of Sponsoring}

Organizations (COSO) menjelaskan tentang kerangka pengendalian internal yang terdiri dari lima komponen dan terdiri dari 17 prinsip yang membangun serta mendukung konsep. Lima komponen terebut adalah lingkungan pengendalian, penilaian risiko, informasi dan komunikasi, aktivitas pengendalian, serta pengawasan. Setiap komponen tersebut terdapat 2 hingga 5 prinsip di dalamnya (Romney 2014 hlm.230-231).

\section{Lingkungan Pengendalian}

Romney (2014) menjelaskan
lingkungan pengendalian merupakan pondasi atau hal yang terpenting dari komponen pengendalian internal karena dalam lingkungan pengendalian mempengaruhi cara organisasi menetapkan tujuan organisasi, membuat struktur aktivitas bisnis dan mengidentifikasi dan merespon risiko. Lingkungan internal yang lemah akan menghasilkan kegagalan dalam pengendalian internal. Lingkungan pengendalian mencakup tentang organisasi membutuhkan budaya untuk menekankan integritas dan komitmen pada nilai-nilai etis serta kompetensinya, untuk mencapai tujuan entitas, personel pada setiap tingkatan dalam organisasi harus memiliki pengetahuan dan keahlian yang diperlukan untuk melaksanakan pekerjaan mereka secara efektif, partisipasi dewan komisaris dan komite audit memiliki dampak yang besar terhadap lingkungan pengendalian dan pengawasan, Manajemen melalui aktivitasnya memberikan isyarat yang jelas kepada karyawan tentang pengendalian internal yang baik, Struktur organisasi menggambarkan tanggung jawab dan otoritas yang ada dalam perusahaan dan kebijakan dan prosedur sumberdaya manusia yang diterapkan akan menjamin bahwa personel entitas memiliki tingkat integritas, nilai etika, dan kompetensi yang diharapkan

\section{Penilaian Risiko}

Hayes (2017) menjelaskan risiko dapat timbul dari faktor internal maupun eksternal, secara eksternal faktor yang mempengaruhi risiko adalah perubahan teknologi dapat mempengaruhi sifat dasar dalam pengendalian internal, begitu juga dengan faktor internal seperti adanya peluang dalam penyalahgunaan sejumlah asset. Dalam mengidentifikasi risiko bisnis biasanya lebih memprioritaskan sejumlah aktivitas yang berisiko tinggi. Kecurangan dapat terjadi karena adanya perubahan lingkungan operasi, personel baru, sistem informasi yang mengalami perubahan serta produk dan aktivitas baru. Auditor menilai risiko untuk manentukan bukti yang dibutuhkan dalam proses audit.

\section{Aktivitas Pengendalian}

Arens (2015) menjelaskan aktivitas pengendalian adalah beberapa kebijakan dan prosedur yang dapat membantu memastikan tindakan yang perlu diambil untuk mengatasi risiko terhadap pencapaian tujuan pengendalian internal. Pada dasarnya aktivitas pengendalian terdiri dari 5 kategori yang utama yaitu

1. Pemisahan kewajiban yang memadai

Pemisahan penjagaan asset dari akuntansi. Saat seseorang melaksanakan kedua fungsi tersebut, ada suatu kenaikan risiko, pemisahan otorisasi transaksi dari penjagaan asset terkait hal ini dilakukan untuk mencegah orang yang mengesahkan transaksi dan juga mempunyai kendali atas asset terkait, pemisahan tanggung jawab operasional dari tanggung jawab penyimpanancatatan dan juga pemisahan antara kewajiban TI dari departemen pemakai 
2. Otorisasi yang sesuai dari transaksi dan aktivitas

Setiap transaksi harus disahkan dengan benar jika ada seseorang dalam organisasi yang bisa memperoleh dan mengeluarkan asset sesuka hati, akan dihasilkan kekacauan.

3. Dokumen dan catatan yang memadai

Dokumen dan catatan merupakan bukti fisik dimana transaksi dimasukkan dan diringkas dan dipelihara dalam bentuk arsip tetapi dokumen yang tidak memadai biasanya menyebabkan masalah pengawasan yang lebih besar.

4. Pengendalian fisik atas asset dan catatan Untuk melindungi asset dan catatan adalah hal yang sangat penting bagi organisasi jika tidak dilindungi maka asset dan catatan tersebut dapat tercuri.

5. Pemeriksaan independen atas penampilan

Pemeriksaan independen atas penampilan dibutuhkan karena pengendalian internal cenderung untuk berubah seiring waktu kecuali jika ada suatu mekanisme untuk tinjauan ulang yang sering.

\section{Informasi dan Komunikasi}

Arens (2015, hlm. 353) menjelaskan bahwa Informasi dan komunikasi yang relevan dengan tujuan pelaporan keuangan yang memasukkan setiap transaksi kedalam sistem akuntansi dan menjadi subjek dari sejumlah prosedur, yakni memulai, mencatat, memproses dan melaporkan transaksi-transaksi yang dilakukan oleh entitas terkait serta mempertahankan akuntabilitas aset terkait. Sistem akuntansi harus memenuhi tujuan audit seperti kelengkapan, keterjadian, dan lainnya karena untuk memastikan bahwa setiap transaksi telah dicatat dengan benar, tercermin dalam laporan keuangan pada periode yang tepat dan menghindari adanya pencatatan ganda atau pencatatan yang dimana transaksi tersebut belum dilakukan.

\section{Pemantauan}

Arens (2015) menjelaskan pemantauan adalah penilaian berkala atau berkelanjutan dari mutu prestasi pengendalian internal oleh manajemen untuk menentukan bahwa pengendalian itu beroperasi seperti yang diharapkan dan dimodifikasi sesuai dengan perubahan dalam kondisi tertentu. Informasi untuk penilaian dan modifikasi datang dari berbagai sumber, mencakup studi tentang pengendalian internal yang ada, laporan auditor internal, laporan pengecualian atas aktivitas pengendalian, laporan oleh pembuat peraturan seperti agen peraturan bank, umpan balik dari personil operasional, dan keluhan dari luar.

\section{METODE PENELITIAN}

Penelitian ini menggunakan metode kualitatif lebih dimaksudkan untuk memahami masalah-masalah manusia dalam konteks sosial dengan menempatkan peneliti sebagai instrumen penting yang mengumpulkan data dari lingkungan alamiah dan menganalisisnya data secara induktif dan deduktif serta menghasilkan penyajikan data secara menyeluruh dan kompleks, melaporkan pandangan terperinci dari pada sumber informasi, serta dilakukan dalam setting yang alamiah tanpa adanya intervensi apapun dari peneliti (Creswell,2016 hlm.59). Penelitian ini dilakukan untuk meneliti sistem pengendalian internal pada LAZ Al Azhar lebih mendalam melalui lingkungan alamiah serta menganalisis serta menyajikan data secara detail dan melaporkannya informasi tanpa adanya intervensi dari peneliti.

Burrell dan Morgan (Darmayasa,2015) menggambarkan sifat interpretif sebagai paradigma yang memiliki karakteristik untuk memahami dan menafsirkan dunia sosial yang tidak terlepas dari kacamata personal yang terlibat langsung dalam sebuah proses sosial. Peranan sosial masyarakat, penelitian terikat kepada norma-norma, aturan-aturan tertentu dan keyakinan, serta pandangan dan sikap dari informan. 
Paradigma interpretif digunakan peneliti karena digunakan untuk memahami dan menafsirkan realitas sosial dari sudut pandang personal atau partisipan yang yang terlibat langsung dalam suatu proses yang ada dalam Lembaga Amil Zakat.

Pendekatan fenomenologi memfokuskan penelitian untuk memahami esensi dari pengalaman partisipan yang telah mengalami fenomena menjadi deskripsi tentang esensi partisipan tersebut terdiri dari "apa" yang mereka alami dan "bagaimana" mereka mengalami (Creswell,2016 hlm.105). Peneliti menggunakan pendekatan fenomenologi karena ingin merefleksikan dan memaknai pengalaman informan dalam melihat dan mempraktikkan sistem pengendalian internal di Lembaga Amil Zakat (LAZ) Al Azhar. Karena masih adanya ketidakpercayaan masyarakat terhadap LAZ ini yang menyebabkan tidak tercapainya potensi zakat yang ada di Indonesia.

Objek penelitian ini adalah penerapan sistem pengendalian internal Lembaga Amil Zakat (LAZ), apakah sistem pengendalian internal pada aktivitas penghimpunan dan penyaluran dalam LAZ Al Azhar telah sesuai dengan 5 komponen sistem pengendalian internal yang dikeluarkan oleh COSO (Commitee of Sponsoring Oganizations of the Treadway Commision). Sumber data dalam penelitian ini didapat dari informan kunci yaitu pihak internal Lembaga Amil Zakat (LAZ) yang terlibat dalam sistem pengendalian internal. Informan kunci terbagi menjadi 3 informan yaitu internal auditor direktur operasional zakat infaq sedekah dan wakaf dan Kepala divisi keuangan serta adanya informan pendukung yaitu informan yang berkaitan dengan penghimpunan dan penyaluran dana zakat.

Teknik pengumpulan data pada penelitian ini menggunakan wawancara dan dokumentasi. Dalam penelitian ini, peneliti melakukan wawancara berupa tanya-jawab terhadap informan internal yang berkaitan dengan penerapan sistem pengendalian internal pada penghimpunan dan penyaluran dana zakat yang berlaku dalam lembaga. Teknik dokumentasi merupakan teknik pengumpulan data yang dilakukan dengan cara mengumpulkan dokumendokumen lapangan yang terkait dengan objek yang diteliti (Creswell,2016 hlm.242). dokumentasi dengan cara mengumpulkan catatan, dokumendokumen transaksi dalam perusahaan yang terkait dengan sistem pengendalian internal pada Lembaga Amil Zakat Al Azhar.

Proses analisis data mengikuti Moustakas (1994) yang dikutip oleh Sudarsyah (2016) yang dimulai dari membuat daftar jawaban dari informan dengan menunda prasangka peneliti agar jawaban informan lebih terkesan apa adanya, setelah itu reduksi dan eliminasi untuk jawaban yang memang tidak jelas, dan adanya pengulangan, membuat tema terhadap jawaban yang konsisten, melakukan validasi jawaban dengan cara konfirmasi kepada informan lain lalu memaparakan jawaban yang telah tervalidasi

\section{HASIL DAN PEMBAHASAN}

\section{Siklus Dana Zakat di LAZ Al AzharLingkungan Pengendalian}

LAZ Al Azhar membangun kantor pelayanan yang ada di Bintaro, Sentral, dan juga Masjid Agung Al Azhar untuk menghimpun dana zakat. Sementara untuk yang diluar Jakarta LAZ Al Azhar juga memiliki kantor perwakilan yang ada di Jawa Tengah, Sumatera Barat, Jogjakarta, dan Jawa Timur. LAZ Al Azhar telah menggunakan sistem penghimpunan berbasis online maka masyarakat yang membayar zakat nantinya akan memperoleh kuitansi yang mana dapat ditunjukkan sebagai bukti untuk mengurangi harta kena pajaknya. Tugas dari penghimpunan adalah menerima dana zakat, infaq dan shadaqah serta memberi kuitansi kepada donatur untuk fungsi pengawasan dan fungsi catatan. Bu Arin menjelaskan bahwa 
'Iya, karena mereka kan ada akun sendiri di server. Jadi langsung masuk server udah langsung akun mereka." "Kan, log in nih. Log in kita pakai nama kita. Untuk bikin kwitansi, itu log in." "Karena pake server, udah online.' (Manuskrip: Inf.3 Wawancara 26 Desember 2018)

Bagian penghimpunan untuk dapat menginput dana zakat yang masuk dan membuat kwitansi terhadap muzzaki haruslah log in ke server untuk penerimaan zakat. Jika kita tidak diberi wewenang untuk menerima zakat maka kita tidak dapat masuk kedalam server dan tidak bisa untuk input dana yang masuk. Muzzaki yang ingin membayar zakat, infaq pun akan dilayanin dengan benar. Setelah penerimaan uang dilakukan maka tahap selanjutnya menyerahkan uang dari kantor pelayanan ke kantor pusat. Penyerahan uang ke kantor pusat membutuhkan waktu setidaknya seminggu setelah diterimanya uang. Karena tidak setiap hari LAZ Al Azhar mendapatkan penerimaan dari dana zakat, infaq, shadaqah pada periode tertentu penerimaan zakat banyak dan pada periode selajutnya sedikit. Bagian keuangan yang menerima dana zakat, infaq atau shadaqah akan mengecek kembali uang dan catatan yang ada di dalam server. Pak farid menjelaskan

\footnotetext{
'Sebetulnya orang yang sama itu pasti kan dia input, lalu terima duit, lalu duit itu di oper ke Manajer Keuangan, lalu kita cek lagi antara uang dengan dokumennya. Lalu uang itu disetorkan ke Bank, catet lagi. Jadi fungsi Control itu sudah berlapis-lapis.' (Manuskrip: Inf.2 Wawancara 17 Desember 2018)
}

Bagian keuangan mengecek lalu uang tersebut disetor ke bank jadi pemeriksaan uang terhadap dokumen yang masuk. Ketika uang tersebut di serahkan ke bagian keuangan akan di cek antara kuitansi dengan uang yang diterima. Penghimpunan zakat juga memiliki standar operasional pekerjaan (SOP) yang diterapkan terkadang mungkin karyawan melencemg dari SOP nya saat bekerja oleh sebab itu pengawasan terhadap karyawan harus dilakukan oleh atasan atau. Bu Arin menjelaskan

\footnotetext{
'Nggak, kalau Fatmawati paling dari Kadivnya. Ngontrol satu-satu kantor layanan. Karena kan
}

kita kantor layanan dibawah fundraising kan, jadi Kadiv fundraising-nya yang kontrol disetiap pelayanan. Kan ada di Sentral, ada di Bintaro. Mereka yang sidak ke kantor pelayanan' (Manuskrip: Inf.3 Wawancara 26 Desember 2018)

Kantor layanan digunakan oleh LAZ Al Azhar untuk menghimpun dana untuk menjangkau para donatur yang mungkin mau membayar zakat secara langsung tempat untuk membayar zakat tersebut terletak di Bintaro, Masjid Agung Al Azhar dan lainnya. Kantor layanan ini di awasi sendiri oleh kepala divisi fundrising dan sering ada pemeriksaan didalamnya apakah pekerjaan mereka telah sesuai atau belum makanya sering dilakukan sidak ke kantor layanan LAZ Al Azhar. Setelah melakukan penghimpunan LAZ Al Azhar melakukan Penyaluran dana zakat, infaq dan shadaqah (ZIS) dilakukan oleh divisi program dilakukan setelah adanya keputusan dari dewan komisaris.yang menggunakan RAB (Rencana Anggaran Biaya) dibuat oleh LAZ Al Azhar yang nantinya diperiksa oleh direktorat. Direktorat mengambil keputusan menyetujui atau tidaknya $\mathrm{RAB}$ tersebut untuk nantinya dana zakat disalurkan ke 8 Asnaf tadi.

\section{Analisis sistem pengendalian internal menggunakan komponen yang dikeluarkan oleh COSO}

\section{Lingkungan Pengendalian}

LAZ Al Azhar juga memiliki standar etika untuk dipatuhi etika tersebut seperti penampilannya harus yang islami tidak boleh senonoh, disiplin tepat waktu, dan adanya SOP untuk melakukan pelayanan terhadap muzzaki (pemberi dana zakat). Karyawan dituntut untuk memiliki pengetahuan dan keterampilan yang sesuai dengan pekerjaan. Untuk efisiensi dan efektifitas dalam kinerja. Karyawan yang direkrut haruslah yang sesuai dengan kebutuhan dan pengetahuan dan keterampilan yang sesuai dengan kebutuhan Komunikasi yang dilakukan LAZ Al Azhar dengan komite audit tidak 
secara intens atau hanya ketika ingin ada audit yang mau datang. Kantor Akuntan Publik (KAP) yang melakukan audit di LAZ Al Azhar biasanya atas rekomendasi komite audit. Hal ini dilakukan oleh komite audit untuk menilai bagaimana sistem pengendalian internal pada LAZ Al Azhar sudah diterapkan secara baik atau belum. Arens (2015) menjelaskan bahwa dewan yang aktif dan objektif dapat mengurangi kemungkinan manajemen mengesampingkan pengendalian yang ada. Septyan, (2018) menjelaskan bahwa Pemilihan KAP menjadi penting dalam menaikan nilai kebaikan perusahaan dalam hal pengungkapan pada laporan tahunan. Oleh sebab itu peran dari komite audit sebenarnya sudah baik karena dia merekomendasikan KAP untuk LAZ Al Azhar dan menilai pengendalian internal ketika mereka datang langsung ke LAZ Al Azhar. Pemilihan KAP yang baik juga dapat menaikkan nilai kebaikan perusahaan dalam hal pengungkapan laporan keuangan yang diterbitkan oleh LAZ Al Azhar.

Manajemen puncak menekankan pada divisi penerimaan agar dalam melakukan transaksi haruslah menggunakan kuitansi serta mengedukasi para pembayar zakat untuk meminta kuitansi jika tidak diberi kuitansi. Pengendalian internal adalah suatu sistem untuk melihat apakah penerimaan telah dilakukan deNgan baik dimana setiap penerimaan kas atau dana ZIS yang masuk memiliki bukti. Struktur organisasi adalah bagan yang terdapat nama direktur hingga staffnya dan jadi tugas dibagi perdivisi dimana dari penjelasan pak ahidin pun dapat dimengerti bahwa divisi di LAZ Al Azhar memiliki 2 divisi penting yaitu penghimpunan dan penyaluran yang mana dinamakan tim funding dan program. Form peneliaian kinerja telah dibuat oleh LAZ untuk menilai kinerja karyawan secara bertingkat jadi Direktur sebagai jabatan tertinggi dalam Lembaga Amil Zakat Al Azhar menilai kinerja dari General manajer, lalu general manajer menilai bagaimana kinerja dari manajer dan manajer akan menilai kinerja karyawan dibawahnya.

\section{Penilaian Risiko}

Teknologi penerimaan zakat yang telah menggunakan web based ini memang mengeluarkan banyak biaya dari biaya membangun sistem penerimaan, atau gaji para pegawai yang bertugas untuk memperbaiki dan memantau kerja dari sistem yang diterapkan di LAZ Al Azhar. Namun manfaat yang diterima oleh bu Lusianah dan pak Farid diatas mereka menjelaskan bahwa pembangunan sistem penerimaan berbasis web based ini sangatlah membantu dan memberi manfaat bagi LAZ Al Azhar. Penilaian risiko keuangan terhadap biaya yang dikeluarkan untuk pengendalian internal sudah dilakukan oleh LAZ Al Azhar dengan menilai risiko apa saja yang akan timbul seperti maintenance dan beban gaji pegawai yang naik tetapi manfaat yang didapatkan oleh LAZ Al Azhar sangat terasa karena kinerja yang dilakukan menjadi lebih efektif dan efisien.

Pemalsuan data yang dilakukan oleh beberapa orang yang tidak bertanggungjawab sering kali dilakukan untuk mengelabuhi LAZ Al Azhar. Makelar untuk menerbitkan kuitansi palsu memang sudah banyak dilakukan untuk mendaptkan belas kasihan dari pihak LAZ. Surveyor atau yang melakukan survei ke lapangan juga harus menilai apakah orang tersebut memang layak mendapatkan bantuan dana dari LAZ. Pihak LAZ Al Azhar juga menanggapi risiko tersebut bu Liza menjelaskan

\footnotetext{
‘... Terus nanti kan ada proses wawancara, dari wawancara kita mau tahu kehidupan si anak ini di rumahnya seperti apa, pendapatan keluarganya berapa. Kalau dari hasil wawancara aja kurang kuat nih, karena banyak anak yang pandai bersilat lidah kan, jadi kita lakukan survei. Jadi tahapnya itu yang bener-bener kita tahu, kita tuh gak salah untuk menyalurkan dana zakatnya. Ada survei, dan kita biasanya gak langsung datang ke rumahnya. Tapi kita tanya langsung ke warga sekitar sama ke RT-nya.'
} 
(Manuskrip: Inf.4 Wawancara 26 Desember 2018)

Untuk memastikan data tersebut tidak bodong atau palsu pertama-tama dilakukan lah wawancara apakah memang data tersebut asli dan apakah dari hasil wawancara dia masih berhak untuk mendapatkan dana tersebut. Setelah itu adanya survei kesekitaran tempat tinggalnya bertanya langsung kepada warga sekitar tentang orang yang ingin mendapatkan dana tadi. Arens (2015) menjelaskan jika manajemen secara efektif menilai dan merespon risiko, maka auditor akan mengumpulkan lebih sedikit bukti ketimbang jika manajemen gagal mengidentifikasi atau merespon risiko yang signifikan. Pernyataan manajemen dalam menilai risiko karyawan sangatlah baik dari ketika baru pertama kali masuk sudah di nilai risikonya dimana manajemen menilai masa lalunya dan membuatkan SOP untuk mengaturnya agar tidak terjadi kecurangan yang dilakukan oleh karyawan. Begitu pula dengan adanya teknologi yang diterapkan oleh LAZ Al Azhar pencurian data dan kesalahan dalam input pun sudah dinilai dan direspon dengan adanya perlindungan oleh tim IT dan adanya pengecekan kembali. Serta untuk pengeluaran sering adanya surat palsu pun sudah di respon dengan adanya survei lapangan dan juga wawancara. Jadi auditor yang ingin memeriksa LAZ Al Azhar hanya perlu mengumpulkan sedikit bukti audit untuk di lakukan pemeriksaan.

\section{Aktivitas Pengendalian}

Bagian keuangan programlah yang memegang uang tersebut dari penjelasan bu Liza menyatakan bahwa dia yang menyimpan dan mengatur untuk keluarnya uang tersebut. Pemisahan otorisasi ini sudah baik karena meminimalisir kecurangan yang akan dilakukan oleh manajer jika dia membuat PPD dan dia yang mengeluarkan bisa saja ada manipulasi dana zakat atau infaq tersebut yang mungkin keluar bukan untuk yang berhak namun untuk pengeluaran pribadi. Oleh sebab itu setiap program di LAZ Al Azhar memiliki bagian keuangannya masing-masing agar pemisahan antara otorisasi dan penyimpanan asset bisa berjalan dan tidak ada indikasi kecurangan.

Jika ada PPD masuk maka pak Farid selaku kepala divisi keuangan diberitahu. Karena pada jumlah tertentu pak Farid yang menyetujui dan memeriksanya. telah dilakukan dengan benar. Arens (2015) menjelaskan agar pengendalian berjalan efektif maka suatu transaksi harus diotorisasi dengan tepat. Penghimpunan di LAZ Al Azhar dilakukan oleh divisi Fundrising dan diotorisasi oleh yang menerima dana karena pertanggungjawaban ada di penerima tersebut. Bagian program yang melakukan penyaluran juga ada otorisaasi untuk meminta dana haruslah meminta izin pada manajer program hingga direktur tergantung pada nominal yang ingin disalurkan. Bagian keuangan juga memiliki otorisasinya sendiri jika ada divisi program yang ingin meminta dana untuk disalurkan. Otorisasi yang dilakukan perdivisi sudah sesuai karena adanya otorisasi yang bertingkat pada nominal pengeluaran siapa yang harus memeriksa dan menyetujuinya.

Divisi program setelah membuat PPD maka diserahkan ke divisi keuangan untuk dilakukan pengecekkan kembali dan PPD tadi disimpan di LAZ Al Azhar yang ada di fatmawati untuk dokumentasi. Areens (2015) menjelaskan bahwa pengendalian yang berhubungan dengan dokumen dan catatan adalah bagan akun yang mengklasifikasikan akun akun kedalam neraca dan laporan lainnya. Penghimpunan dana yang dilakukan Al Azhar telah baik dimana menggunakan sistem yang berbasis online jadi pengklasifikasian dalam akun infaq umum, infaq khusus dan zakat pastinya akan mudah untuk diklasifikasikan. Sedangkan untuk program sedikit rumit karena memang di PPD dijelaskan untuk apa dana tersebut dijelaskan namun untuk pelaporan seperti disatukan bu Liza menjelaskan 
'Kita kan untuk laporan di keuangannya dijadiin satu, jadi plek RGI, plek gak bisa dirinciin.' (Manuskrip: Inf.4 Wawancara 26 Desember 2018)

Perincian untuk dana yang keluar kurang dapat ditelusuri karena dari program RGI saja misalnya pengeluaran sebesar apa maka di laporan keuangan ditulis sebesar pengeluaran RGI dan tidak dirinci.

'Kalau misalnya uang, biasanya sih saya nyimpennya disini, di brankas.' (Manuskrip: Inf.4 Wawancara 26 Desember 2018)

Brankas berisi uang tidak hanya dimiliki oleh divisi keuangan namun, bagian program pun memilikinya untuk melindungi asset yang dimiliki oleh LAZ Al Azhar. Arens (2015) menjelaskan adanya kota dan ruang penyimpanan tahan api untuk melindungi asset seperti uang dan sekuritas. Hal ini dilakukan oleh LAZ Al Azhar dengan adanya brankas untuk melindungi asset pada kantor layanan, kantor pusat dan divisi program. Pengendalian atas asset dan catatan sudah baik karena adanya brankas untuk uang sebagai asset dari LAZ Al Azhar.

Pemeriksaan yang independen dilakukan dan jika ada yang salah dalam lapangan maka harus di cek. Pak Farid selaku kepala divisi keuangan menegur langsung jika ada laporan yang kurang berkenan mungkin pembelian untuk barang barang tertentu yang mungkin tidak dibutuhkan ataupun pembelian yang mungkin tidak ada kuitansinya. Arens (2015) menjelaskan pengendalian internal cenderung berubah seiring dengan berlalunya waktu, personil mungkin telah sengaja atau tidak disengaja telah membelot dari prosedur yang telah ditetapkan sebelumnya. Pemeriksaan seperti cash opname harus dilakukan untuk menghindari kesalahan input nominal pada uang yang mengeluarkan atau menerima uang. Serta pelaporan dari departemen harus diperiksa lagi kebenarannya karena bisa saja laporan kurang dalam memberikan bukti.

\section{Informasi dan Komunikasi}

Tujuan audit berkaitan dengan kelengkapan dapat dilihat dari yang ada dalam laporan realisasinya yang jika uang kurang maka akan minta balik dan jika kelebihan maka akan di kembalikan. Keterjadian dan keakuratan juga dapat dilihat dari kuitansi yang ada dan dapat dikonfirmasi kepada penerima dana tersebut karena yang bersangkutan menulis nomornya di kuitansi. Dari penjelasan diatas kita dapat mengetahui transaksi utama LAZ Al Azhar adalah menghimpun dan menyalurkan dana ZIS. Transaksi menggunakan cash basis jadi pencatatan dilakukan ketika uang diterima atau uang keluar. Catatan akuntansi terdiri atas kuitansi penerimaan ZIS, PPD dan laporan realisasi penyaluran yang di buat oleh divisi program. Rincian dari penghimpunan zakat dimulai dari penerimaan, lalu dicek kuitansi, angka yang disistem dan uang realnya. Untuk penyaluran dana pertama kali harus membuat PPD yang disetujui oleh beberapa orang dan dikirim ke divisi keuangan dan disetujui lagi setelah itu uang baru cair. Pertanggung jawaban dari divisi programpun dijelaskan dari laporan realisasinya ke divisi keuangan setelah itu diabndingkan kuitansi serta laporannya.

\section{Pemantauan}

Fungsi auditor internal secara personal dalam LAZ Al Azhar sebenarnya belum ada. Jadi yang mengawasi sistem pengendalian internal ya seperti bu Lusianah, pak Farid dan bawahannya bu Lusianah. Hal ini menyatakan bahwa indepedensi laporan audit internal dari auditor internal masih diragukan karena yang melakukan fungsi audit internal sendiri dia melakukan kegiatan dalam operasi yaitu menyetujui adanya PPD maupun dalam akuntansi yang mencatat dan membuat laporan keuangan. Namun, adanya audit tahunan yang direkomendasikan oleh komite audit dan selalu mendapatkan opini wajar tanpa pengecualian ini dapat dipertanggung jawabkan tingkat indepedensinya pasti 
besar karena dipilih langsung oleh komite audit.

\section{SIMPULAN}

Berdasarkan penjelasan dan pembahasan mengenai Sistem Pengendalian Internal yang terkait lima komponen COSO yang diterapkan oleh Lembaga Amil Zakat (LAZ) Al Azhar, mengenai penghimpunan serta penyaluran dana zakat dapat diambil kesimpulan pada lingkungan pengendalian sudah diterapkan secara baik manajemen menjunjung dan menasihati karyawannya untuk selalu bekerja secara jujur dan tidak melakukan penyimpangan dan Lembaga Amil Zakat menilai risiko untuk karyawan, perubahan dalam bidang teknologi dan adanya formulir bodong dari pihak ketiga yang ingin mendapatkan uang bantuan. Hal ini direspon dengan adanya tingkat peraturan yang diterapkan oleh manajemen, backup data dan penjagaan server agar tidak di serang, dan adanya survei untuk para penerima dana ZIS.

Aktivitas Pengendalian telah dilakukan pemisahan tugas yang baik antara penyimpanan asset dari akuntansi, pemisahan otorisasi transaksi dari penyimpanan asset dan pemisahan antara divisi IT dengan departemen pemakai. Otorisasi yang di lakukan oleh pejabat yang bersangkutan dengan transaksi yang benar, penyimpanan dokumen yang baik karena bersifat computer base. Transaksi menggunakan cash basis jadi pencatatan dilakukan ketika uang diterima atau uang keluar. Belum adanya auditor internal yang terpisah dari kegiatan operasi dan kegiatan akuntansi membuat fungsi audit internal kurang efektif dan diragukan indepedensinya. Namun adanya audit setiap akhir tahun oleh audit eksternal maka dapat disimpulkan laporan auditor eksternal independent katrena dipilih atau direkomendasikan oleh komite audit

\section{Rekomendasi}

Setelah mengadakan penelitian dan menganalisisnya, maka penulis dapat memberikan saran yang digunakan sebagai bahan pertimbangan atau masukan bagi manajemen Lembaga Amil Zakat Al AzharPerlu adanya orang yang menangani audit internal yang jabatannya tidak tumpang tindih dengan manajer ataupun kepala divisi keuangan atau bisa dibilang memiliki orang yang independent yang menangani audit internal

\section{REFERENSI}

1. _.Undang-Undang Republik Indonesia Nomor 23 Tahun 2011 tentang pengelolaan zakat, Jakarta, 2012.

2. Agoes, Sukrisno, Auditing. Edisi Keempat, Jakarta: Salemba Empat, 2014

3. Arens, Alvin A., Randal J. Elder, Mark S. Beasley, Auditing dan Assurance Services, Edisi Kelimabelas, New Jersey: Pearson Education, Inc, 2015.

4. Badan Amil Zakat Nasional, Outlook Zakat Indonesia 2018. Jakarta: Pusat Kajian Strategis Badan Amil Zakat Nasional (BAZNAS), 2017.

5. Cresswell, Jhon W, Penelitian Kualitatif \& Desain Riset: memilih diantara Lima Pendekatan, Edisi 3, Yogyakarta: Pustaka Belajar, 2018.

6. Departemen Agama RI, Al-Qur'an dan terjemahannya, Bandung: PT. Sygma Examedia Arkanleema, 2007.

7. Djaelani, Aunu Rofiq, Teknik Pengumpulan Data Dalam Penelitian Kualitatif, Majalah Ilmiah Pawiyatan. Vol : Xx, No : 1, 2013.

8. Darmayasa, I Nyoman, Yuyung Rizka Aneswari, Paradigma Interpretif Pada Penelitian Akuntansi Indonesia, Jurnal Akuntansi Multiparadigma Volume 6 Nomor 3 Halaman 341-511, 2015.

9. Friyanti, Yunida Een, Akuntansi Lembaga Zakat dan Wakaf, Cetakan I. Yogyakarta: Pustaka Pelajar, 2017.

10. Hayes, Rick, dkk., Prinsip-Prinsip Pengauditan, Jilid 1 Edisi 3, Jakarta: Salemba Empat, 2017.

11. Nikmatuniayah, Komparasi Sistem Pengendalian Internal Pengelolaan 
Lembaga Amil Zakat. Jurnal Akuntansi Multiparadigma Jamal Volume 5 Nomor 3 Halaman 345-510

12. Nurhayati, Evaluasi Sistem Pengendalian Intern Dalam Pengelolaan Zakat Pada Badan Amil Zakat Nasional Kabupaten Rokan Hulu, Jurnal Ilmiah Cano Ekonomos Vol. 5 No. 2, 2016.

13. Rahman, Jeni, Evi Martaseli, Pengaruh Pengendalian Internal Terhadap Pengelolaan dan Pendistribusian Zakat Pada Badan Amil Zakat Nasional Kota dan Kabupaten Sukabumi, Jurnal Ilmiah Ilmu Ekonomi Vol.6 Edisi 12, 2018.

14. Romney, Marshall B, Paul John Steinbart, Sistem Informasi Akuntansi. Edisi ketigabelas, Diterjemahkan oleh : Kikin Sakinah, Nur Safira dan Novita Puspasari, Penerbit Salemba Empat, Jakarta, 2014.

15. Septyan, K, Determinasi Tingkat Pengungkapan Di Beberapa Negara. Jurnal Akuntansi dan Keuangan islam, 127-141, 2018.

16. Shamsuddin, Noraini, Nazifah Mustaffha, Norhanizah Johari, Internal Audit in Zakat Institutions: Structure and Operational Activities, Proceeding of the $4^{\text {th }}$ International Conference on Management and Muamalah, 2017. 